\title{
Code of Federal Regulations Method
}

National Cancer Institute

\section{Source}

National Cancer Institute. Code of Federal Regulations Method. NCI Thesaurus. Code C96164.

A method described in the Code of Federal Regulations. 